\title{
Administrative, Infrastructural and Finance Related Factors Affecting Private Investment in Ethiopia: Evidence from East Gojjam Zone of Amhara Regional State
}

\author{
Abebe Birhanu Ayele \\ College of Business and Economics, Department of Accounting and Finance, Debre Markos University, \\ P.O.Box 269, Debre Markos Ethiopia
}

\begin{abstract}
The aim of this paper is to identify the main factors related to administrative, infrastructure and market related issues affecting private investment activities in East Gojjam zone with the intention of providing valuable information about the investment environment of the zone to potential investors. Descriptive type of research design has been used in this study by giving more emphasis on qualitative data analysis method. On the other hand, quantitative research analysis has been used to provide numerical measurement and analysis of the magnitude and extent of the problem and trend of private investment in the Zone. The study used both primary and secondary data. Pre-designed self-administered questionnaire has been used to collect primary data. The outcome of this study revealed that, the major bottlenecks of investment in East Gojjam related to administrative and policy related factors include policy distortions and rent seeking, direct government involvement in some investment areas, corruption and dysfunction of the judiciary system, malpractices in granting licenses of investment activities, favoritism in tax revenue collection, arbitrary and inappropriate enforcement of business regulations, bureaucracy and policy implementation delay. Whereas, infrastructural factors affecting private investment include inadequate electric energy, poor water supply and transportation and communication problems. Shortage of foreign currency, fluctuations of exchange rates, access to credit in formal financial institutions, inadequate amount of loan, high interest rates, and bureaucracy of lending institutions to give loan are finance related factors affecting private investment in the study area.
\end{abstract}

Keywords: Private Investment, East Gojjam

DOI: $10.7176 / \mathrm{EJBM} / 12-34-05$

Publication date: December $31^{\text {st }} 2020$

\section{Introduction}

According to the report of United Nations Conference on Trade and Development (UNCTAD) (2002), Investment is one of the primary engines of growth in all economies. However, its effectiveness rests on strong complementarities with other elements in the growth process, most notably technological progress, skills acquisition and the development of innovative capability. These elements make investment a natural point of departure for Governments seeking to formulate a robust development strategy. In fact, in the world, there is no smooth development that can be achieved rather than passing through a series and complex stages of activities. Now a day the development of any country is determined by improved investment activity. Without investment activity it is not possible to have any development rather to remain in the circle of poverty. This is especially true in developing countries like Ethiopia.

Developing countries' governments give much emphasis and energy to attract private investment believing this will overcome constraints on economic growth through promoting technology transfer, creating employment opportunity and attracting other investors in a more diversified economy. In doing so, developing countries have launched specific concerned bodies to facilitate and provide support to investors (Peferman and Madarasy,1992).

To speed up the economic and social development of the country, the efficient and effective utilization of these resources are typical. Investment has a great role in the development of an economy. Therefore, improving investment activity in the way in which development is possible for a country under poor nation. So, due attention must be given to the cause of low level investment activities, by identifying and conducting study from time to time on the opportunities and challenges to achieve the desired result which is, sustainable economic development.

Financing, and infrastructure remain the key constraints faced by business in Ethiopia. However, these constraints are partly manageable in the short term by bringing own financing, technology and process management to Ethiopia in order to transfer knowledge processes to the local workforce. Infrastructure constraints are not prohibitive in most cases and can be managed through proper site selection.

Factors affecting private investment have been substantially studied by different researchers, (Morisset, and Jacques 2000; Basu and Srinivasan, 2002; Salish, and Mohammed, 2003). These and other researchers investigated their study on this area and identified the opportunities and challenges in different countries and areas. However, almost all of these studies conducted on developed and large areas. From such findings it is difficult to generalize the same result in East Gojjam zone. As per the researchers knowledge research studies on factors affecting private 
investment in East Gojjam zone remained an ignored area of study. Thus, with these serious shortcomings of the current literature, this study will contribute to the existing literature

By considering the above situations, the researchers were motivated to conduct this study to identify the major factors affecting private investment in the zone. Generally, this study is conducted with the aim of providing answers for the following basic research questions:

1. What are the major factors related to administrative issues affecting private investment activities in East Gojjam zone?

2. What are the main infrastructural factors affecting private investment in East Gojjam zone?

3. What are the finance related factors affecting private investment in the study area?

\section{OBJECTIVES OF THE STUDY}

\subsection{General Objective}

The general objective of the study is to examine factors affecting private investment activities in East Gojjam zone.

\subsection{Specific Objectives}

In addition to the general objective, the study has the following specific objectives:

1. To identify the major administrative factors affecting private investment activities in East Gojjam zone

2. To assess the main infrastructural factors affecting private investment in East Gojjam zone

3. To investigate finance related factors affecting private investment in the study area?

\section{METHODOLOGY}

This section of the research explains the research design, the data collection and the sources of data, the sampling design, the methods used in the analysis of data and to provide answers to the research questions set out in chapter one of the study.

\subsection{Research Design}

The researchers have employed descriptive type of research design by giving more emphasis on qualitative data analysis method. Qualitative research analysis has been applied to explain the challenges and opportunities of private investment in East Gojjam Zone and to obtain systematic sequence of information to get into the depth of research problems. On the other hand, quantitative research analysis has been used to provide numerical measurement and analysis of the magnitude and extent of the problem and trend of private investment in East Gojjam Zone.

\subsection{Sources of Data}

Data for this study were collected from both primary and secondary sources of data. Primary data were obtained from selected investors in East Gojjam Zone and East Gojjam zone investment and trade bureau. Secondary data were obtained mainly from different reports of East Gojjam Zone office, which are relevant to the theme of the study.

\subsection{Methods of Data Collections}

Pre-designed self-administered questionnaire has been used to collect primary data. Pre-designed self-administered questionnaires have been employed and filled by the managers of the investment sectors in East Gojjam Zone to identify the opportunities and challenges of investment in the zone. Interviews have been used to collect data from East Gojjam zone investment and trade bureau. The investment bureau documents have been used in gathering the necessary data in this study.

\subsection{Sample Size and Sampling Techniques}

The study population of this study were identified based on the proclamation number 37/1996; which says investors should have a capital requirement of birr 1,000,000 and above. Thus, in selecting the study population of this study those investors, who has a capital of birr 1,000,000 and above were included in this study. Based on the report of East Gojjam zone investment bureau from 1,797 total investments in East Gojjam Zone 1365 are in six selected woredas (Debre Markos, Mota, Bichena, Dejen, Amanual and Debre Elias).

The researchers have employed both purposive and stratified sampling techniques to select the actual sample size from the total study population. Generally, the actual sample size of any study is depending on the total population, the research budget and the available time to accomplish the study. Given these in to account, the study utilized the following sample size determining formula to set the actual sample size scientifically (Yaro Yamane, 1967). 


$$
n=\frac{N}{1+N\left(e^{2}\right)}
$$

Where $\mathbf{n}=$ The actual sample size

$\mathbf{N}=$ The total population

$\boldsymbol{e}=$ Degree of accuracy usually set at 0.05

The formula states:

$$
\mathrm{N}
$$

$$
\mathrm{n}=\frac{\mathrm{N}(\mathrm{e}) 2}{1+\mathrm{N})}=\frac{1365}{1+1365}\left(0.05^{2}\right) \quad=310
$$

Sample woredas were selected purposively from east Gijon zone based on their number of investment. For the purpose, six woredas which possess high number of investment were selected. Then, using business types as strata, sample respondents were selected proportionately from each selected woredas. Sample respondents was those investors which were under operation at least for the previous one year period and still are in operation at the time of undertaking the survey.

From the total population of 1365 investors in the six selected woredas of east Gojjam zone (Debre Markos, Mota, Bichena, Dejen, Amanual and Debre Elias), sample of 310 investors were taken as sample respondents based upon the above formula. The sample proportion of each woreda determined by their respective population size is given in the table below.

Table 2: Sample Size Determination by Woredas

\begin{tabular}{|l|l|l|l|}
\hline Woredas/towns & Population & Sample proportion & Actual Sample \\
\hline Debre Markos & 714 & $52.32 \%$ & 162 \\
\hline Mota & 349 & $25.58 \%$ & 79 \\
\hline Bichena & 159 & $11.63 \%$ & 36 \\
\hline Dejen & 48 & $3.49 \%$ & 11 \\
\hline Amanual & 32 & $2.33 \%$ & 7 \\
\hline Debre Elias & 63 & $4.65 \%$ & 15 \\
\hline Total & $\mathbf{1 , 3 6 5}$ & $\mathbf{1 0 0} \%$ & $\mathbf{3 1 0}$ \\
\hline
\end{tabular}

The researchers identified the actual sample of each town by each sector. The table below also shows the actual sample size in each town for their respective investment sector.

\begin{tabular}{|l|c|c|c|c|c|c|}
\hline \multirow{2}{*}{ Town } & \multicolumn{7}{|c|}{ Sector } \\
\cline { 2 - 7 } & Manufacturing & Construction & Urban Agriculture & Service & Trade & Total \\
\hline D/ Markos & 67 & 7 & 11 & 14 & 63 & 162 \\
\hline Mota & 32 & 4 & 5 & 7 & 31 & 79 \\
\hline Bichena & 15 & 2 & 2 & 3 & 14 & 36 \\
\hline Dejen & 4 & 1 & 1 & 1 & 4 & 11 \\
\hline Amanual & 2 & 1 & 1 & 1 & 2 & 7 \\
\hline D/ Elias & 6 & 1 & 1 & 1 & 6 & 15 \\
\hline Total & 126 & 16 & 21 & 27 & 120 & $\mathbf{3 1 0}$ \\
\hline
\end{tabular}

\section{RESULTS AND DISCUSSION}

The main factors affecting private investment are depicted in the following part of analysis. These factors are categorized in to three subdivisions: administrative and policy related factors, the physical and other infrastructural barriers, and factors related to access to finance. The respondents were asked to give Likert scale value for these factors from 1- 5(strongly disagree to strongly agree) depending on the degree of challenge of these variables. If the mean score value of the analysis is below 3 , it indicates the variables are opportunities of private investment in East Gojjam Zone while if it is above 3, the variable are factors which affect private investment negatively in East Gojjam Zone. Accordingly, the mean value of each variable was computed and summarized below: 


\subsection{Administrative and Policy Related Factors Affecting Private Investment}

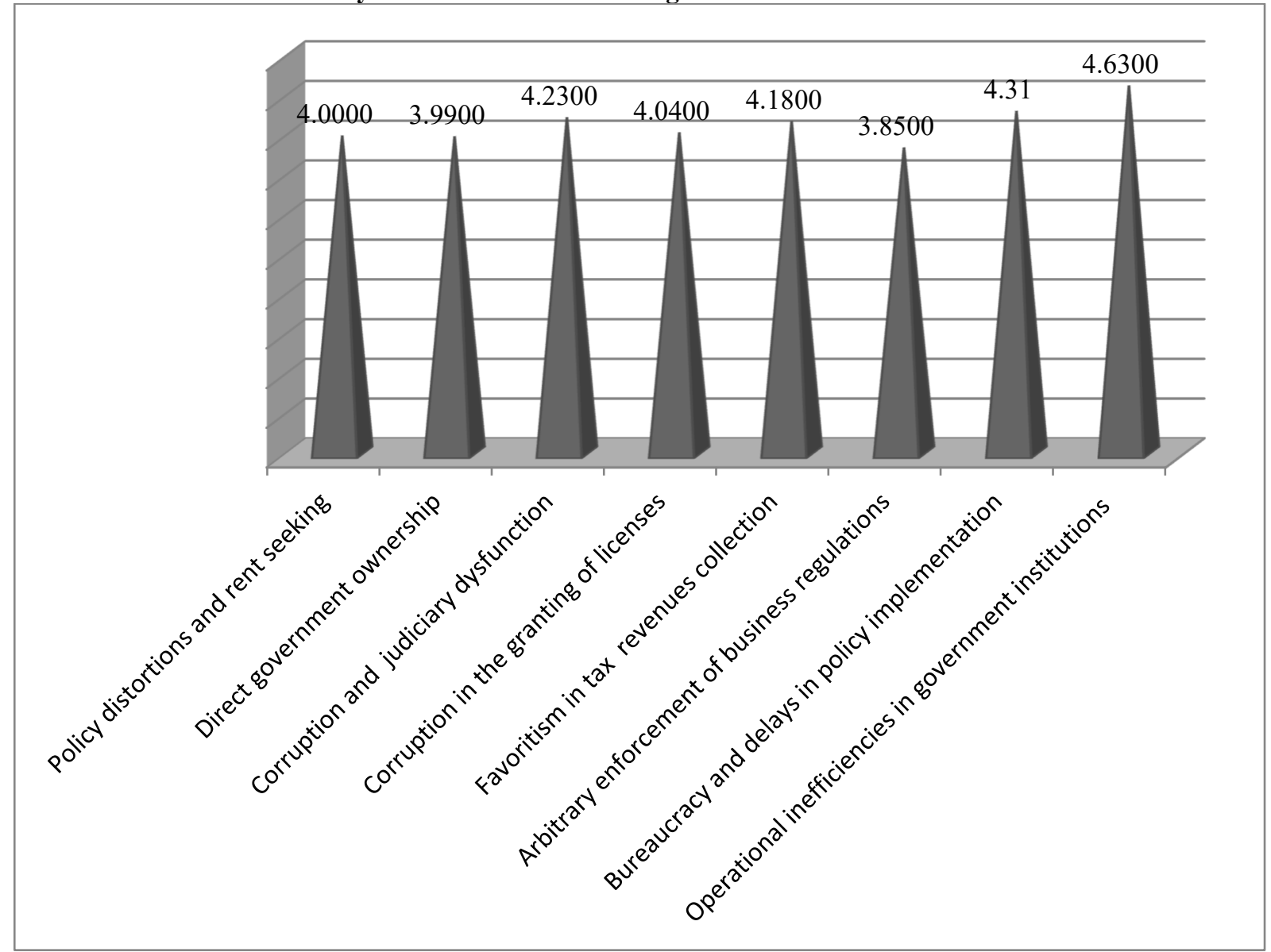

\section{Chart 4.1. Administrative and Policy Related Factors}

As per chart 4.1. above, administrative and policy related factors like policy distortions and rent seeking, direct government involvement in some investment areas, corruption and dysfunction of the judiciary system, malpractices in granting licenses of investment activities, favoritism in tax revenue collection, arbitrary and inappropriate enforcement of business regulations, bureaucracy and policy implementation delay have brought major hindrances on the investment activities in East Gojjam zone all having a mean score close to 4.00. This means, majority of the investors in the zone agree that the above administrative and policy related factors are their major problems for their investment activities. Among these factors, operational inefficiencies of those government institutions is considered as the main obstacle by majority of private investors in the study area having a mean value of 4.63 which close to 5 . That is they strongly agree that operational inefficiencies of some government offices which have affinity of investment activities deter significantly their investment practices. Emery (203), apparently clarifies the quality of governance directly affects the level and nature of private investment in a given country. He explained the relationship of governance to private investment is complex and is subject to many influences governance/ administrative issues like policy distortions, rent seeking, use of direct government ownership for political and patronage objectives, corruption and dysfunction of the judiciary system, corruption in the granting of investment licenses, tax collection favoritism, and others significantly affect investment in the private sector. degree of openness, previous value of inflation rates and governance indicators are the most important factors but political stability and voice and accountability indicators appear to dominate the governance indicators space as they are both negative and significantly affecting the private investment mobilization (Ajide ,2013). Likewise, unpredictable and inefficient investment climate (which could be due to reasons such as frequent changes of investment policies and requirements, inefficient bureaucracy, prolonged poor governance and rampant corruption among others), would deteriorate investors' confidence and appetite (Adugna, 2013)

\subsection{Infrastructural and Related Factors Affecting Private Investment}

According to chart 4.2 below, except unavailability of working age people in the investment area, other factors which include electricity, water supply, inadequate transport and communication system, unavailability of health and educational facilities are all problems of private investment in the study area. Particularly, inadequate electric energy, 
water supply and transportation and communication having a mean score of 4.91, 4.76, and 4.69 are considered as major problems of private investment by majority of the respondents as their mean value is close to 5.00. Access to education and health facilities have a relatively less degree of influence compared to the above variables as their mean values are close to 4:00. Unavailability of working age people is considered as a problem for private investment in the area as its mean score is close to 2:00. This means, this variable can instead be an enabling condition/ opportunity for private investment in the zone. The results of different studies substantiate our findings. Samuel (2011), highlighted Government Capital Spending and Financing and its Impact on Private Investment in Kenya identified that Investment in infrastructure has an insignificant positive effect on private investment in Kenya. public infrastructure (represented by the kilometers of roads per capita) is found to have a positive effect on private investment in the short run (Pradyumna ,2013)

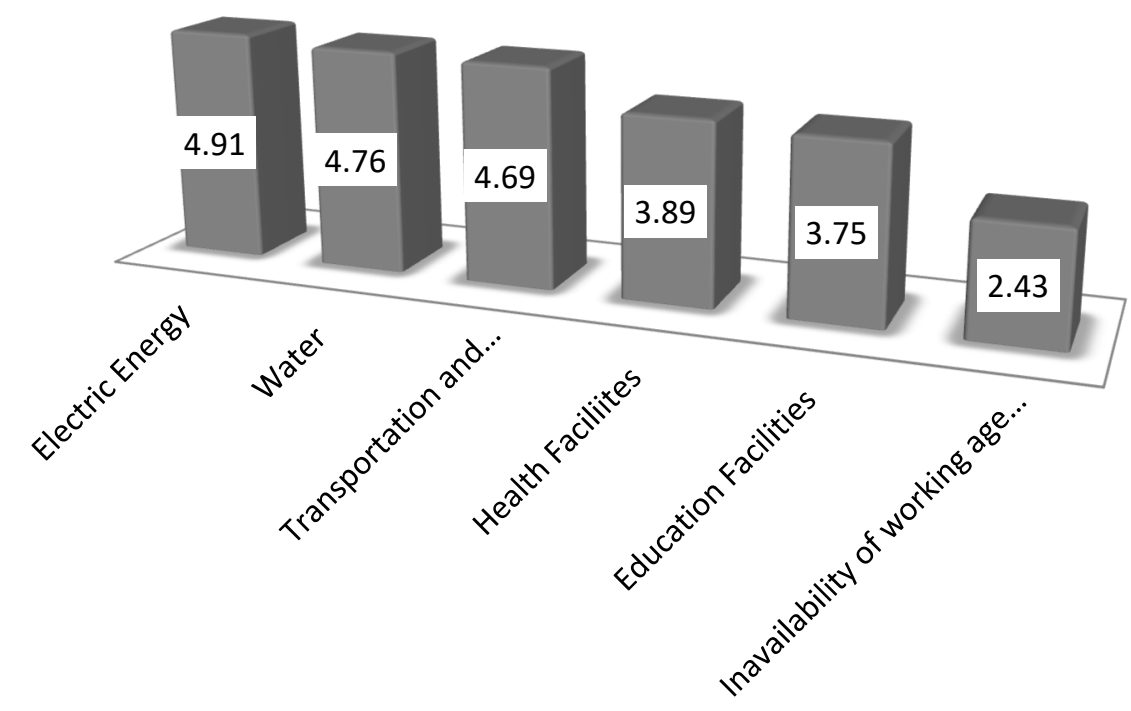

Chart 4.2. Infrastructure and others

\subsection{Finance Related Factors Affecting Private Investment}

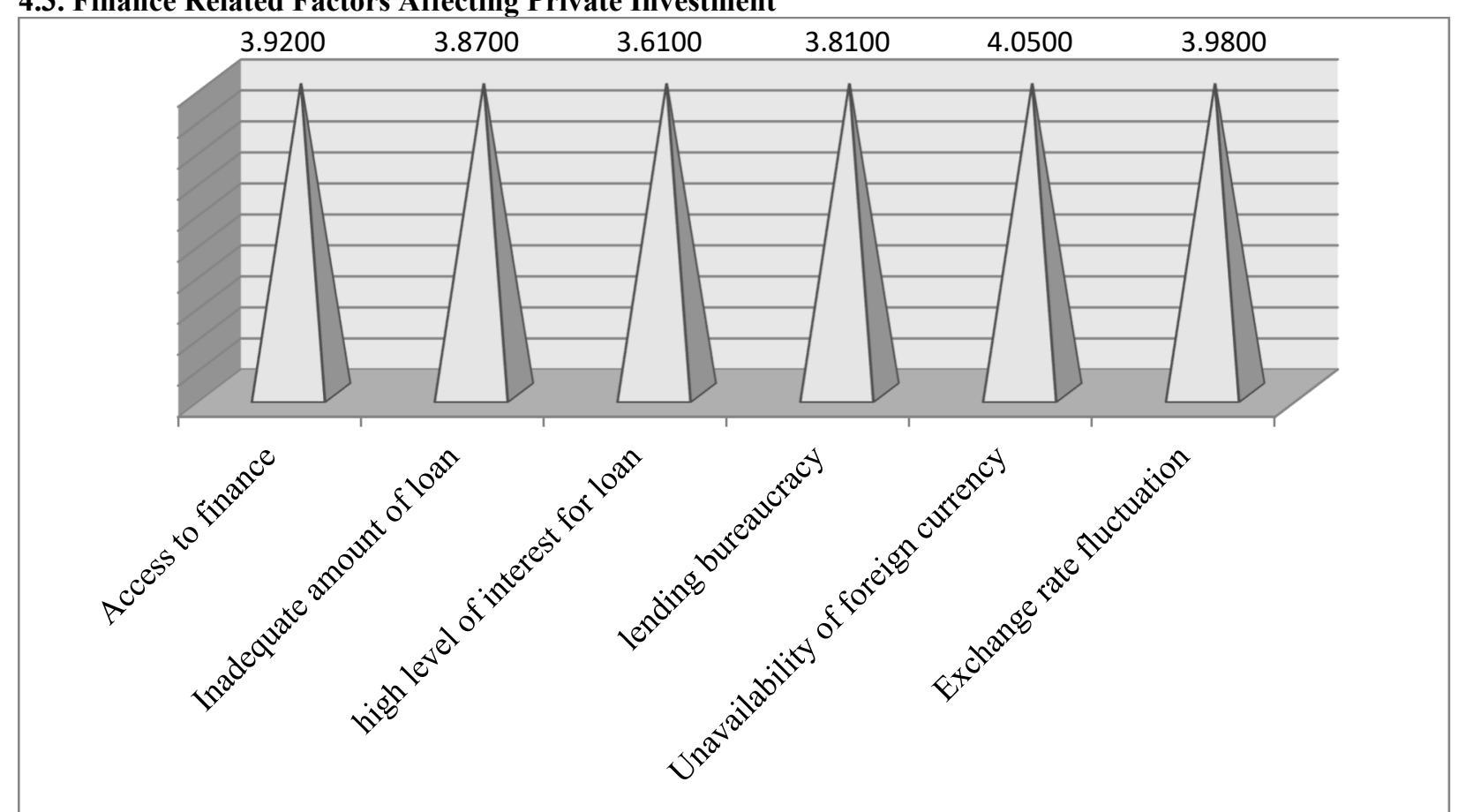

Chart: 4.3.Finance Related Factors 
The degree of challenge investors faced with finance related factors is depicted by the above chart 4.3. Though they are macroeconomic variables which have a nationwide effect, unavailability of foreign exchange reserves and exchange rate fluctuations are the main problems hamper their investment activities in the study area having a mean score of 4.05 and 3.98 respectively which are close to 4.00 (agree). This means that majority of the investors agree that shortage of foreign currency, particularly the USD, and fluctuations of exchange rates significantly discourages their investment. Other variables which include access to credit in formal financial institutions, inadequate amount of loan, high interest rates, and bureaucracy of lending institutions to give loan are all affecting investment practices in East Gojjam zone significantly having a mean value of $3.92,3.87,3.61$ and 3.81 which are very close to 4.00 (agree). Compared to the previous two finance related factors, they bring a lesser influence up on investors' activities in the zone. Findings of earlier studies made in different parts of the world support our findings. For instance, investment credit, interest rates, inflation have negative significant effect on private investment (Nainggolan, et al, 2014). Exchange rate, access to credit, inflation rate, and money supply are among those variables affecting the performance of private investment (Muhidin 2016). Lack of adequate credit will bring a reduction in reduction in the level of private investment with adverse effect on the long term productive capacity of the private sector (Kehinde et.al. 2012))

Policies like deepening financial liberalization, improve the efficiency of the commercial banking system, promote deepening of capital markets, scale up support to SME financing through partial credit guarantees, promote financial innovation, promote creation of credit bureaus etc are need to be done so as to increase business enterprises' access to credit (Fiestas and Sinha , 2011). Acosta and Loza (2005), also highlighted expected rates of return, real exchange rate, inflation although its immediate impact seems to stimulate investment, with time, the effect seems to vanish and become negative are important determinants of private investment in the short run. Credit availability allows higher levels of private investment.

\section{CONCLUSIONS}

Administrative and policy related factors like policy distortions and rent seeking, direct government involvement in some investment areas, corruption and dysfunction of the judiciary system, malpractices in granting licenses of investment activities, favoritism in tax revenue collection, arbitrary and inappropriate enforcement of business regulations, bureaucracy and policy implementation delay have brought major hindrances on the investment activities in East Gojjam zone. Among these factors, operational inefficiencies of those government institutions are considered as the main obstacle by majority of private investors in the study area.

Infrastructure related factors such as Electricity energy, water, transportation and communication, health facilities, education facilities and unavailability of working age people are investigated whether they are factors or opportunities of investment. Electricity energy, water, transportation and communication, health facilities, education facilities are considered as obstacle by majority of private investors in the study area, except unavailability of working age people in the investment area which is opportunity of investment in the area.

Macroeconomic variables which have a nationwide effect, unavailability of foreign exchange reserves and exchange rate fluctuations are the main problems hamper their investment activities in the study area. Other variables which include access to credit in formal financial institutions, inadequate amount of loan, high interest rates, and bureaucracy of lending institutions to give loan are all affecting investment practices in East Gojjam zone significantly.

\section{REFERENCES}

Gebremeskel Awet Wedaj et al. (2015) Assessment of private investment in tigray, northern Ethiopia: challenges and opportunities in the case of manufacturing sector: International Journal of Current Research Vol. 7, Issue, 01, pp.12210-12217.

Basu, et al (2002), Foreign Direct Investment in Africa - Some Case Studies. IMF Working Paper 61.

Hailu Adugna (2013) Determinates of private investment in Ethiopia, Journal of Economics and Sustainable Development ISSN 2222-1700 (Paper) ISSN 2222-2855 (Online) Vol.4, No.20, 2013

Majeed, M.T. and S. Khan (2008) 'The Determinants of Private Investment and the Relationship between Public and Private Investment in Pakistan', Journal of Businessand Economics

Muhdin Muhammedhussen Batu. Determinants of Private Investment: A Systematic Review. International Journal of Economics, Finance and Management Sciences. Vol. 4, No. 2, 2016, pp. 52-56. doi: $10.11648 /$ j.ijefm.20160402.13

Pinondang Nainggolan,et.el, An Analysis of Determinant on Private Investment in North Sumatra Province, Indonesia, Journal of Management Research ISSN 1941-899X2015, Vol. 7, No. 1

Oakland Institute's (2010). Understanding land investment deals in Africa: Ethiopia.

Peffermann, G.P. and A. Madarassy (1992) 'Trends in Private Investment in DevelopingCountries': International Finance Corporation: The World bank, Washington D.C.

Salisu, \& Mohammed (2003), Foreign Direct Investment in Sub-Saharan Africa, The management School, 
Lancaster University.

World Bank, (2004).Opportunities and challenges for developing high-value agricultural exports in Ethiopia.

Kehinde .O.et al . 2012. The Determinants of Domestic Private Investment in Nigeria. IOSR Journal of Humanities and Social Science (JHSS)

Emery J. James. 2003. Governance, Transparency and Private Investment in Africa. Global Forum on International Investment. Johannesburg, South Africa

Agidew Esubalew Tadele. 2014. Determinants of Domestic Private Investment; Evidence from East Africa; International Institute of Social Studies

Ajide Kazeem Bello. 2013. The Role of Governance on Private Investment in Nigeria: A Preliminary Analysis, Central Bank of Nigeria Economic and Financial Review Volume 51

Adugna Hailu. 2013. Determinants of Private Investment in Ethiopia, Journal of Economics and Sustainable Development, Vol.4, No.20.

Acosta, P., \& Loza, A. (2005). Short and Long Run Determinants of Private Investment in Argentina. Journal of Applied Economics, 2(8), 389-406.

Fiestas. I and S. Sinha (2011) 'Constraints to Private Investment in the Poorest Developing Countries' a Review of Literature'. Department for International Development, London UK.

World Bank Development report (2005) Infrastructure and Financial Sector Development: ISBN 92-64-02586-3 Policy Framework for Investment A Review of Good Practices C OECD 2006

Organization for Economic Cooperation and Development Annual Report (2006)https://www.oecd.org/newsroom/36511265.pdf

Peter, H. (2010) People and Places: Can They Align to BringGrowth to Africa?, center for global development essay, www.cgdev.org/content/publications/detail/1424441

Stephen, G., Charles, O., Nelson, W. \&Nelson W., (2014) Impact of Government Expenditure on Private Investment in Kenya: Researchjournali's Journal of Economics Vol. 2 | No. 8 August | 2014 ISSN 23478233

Yaw, A. (2000) Determinants of Private Investment Behavior:The African Economic Research Consortium P.O. Box 62882 Nairobi, Kenya

Mohammad, B. and Salma, A. (2005). The investment scenario in Bangladish-problems and prospects: Pakistan Journal of social science 3(4): 534-540:2005.

Samuel, o. (2011) Government Capital Spending and Financing and its Impact on Private Investment in Kenya:1964-2006: The African Economic Research ConsortiumP.O. Box 62882 - City Square Nairobi 00200, Kenya

Pradyumna, D. (2013) the impact of public investment on private investment:evidence from India: VIKALPA The Journal for Decision Makers 41(4) 288-307

Conference Board of Canada (2013) The Economic Impact of Ontario's Infrastructure Investment Program: Briefing April 2013: Conference Board research at www.e-library.ca

The United Nations Conference on Trade and Development (UNCTAD) (2002), 